
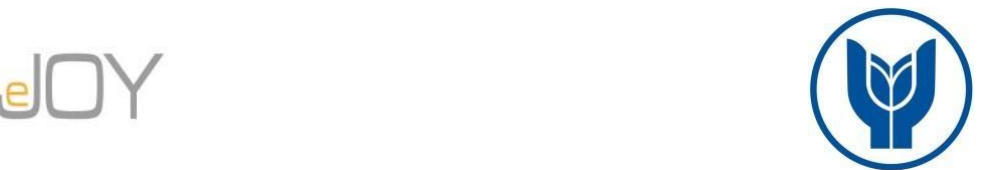

Çelik, C., Yelkikalan, N. / Journal of Yasar University, 2021, 16/62, 659-682

\title{
Makine Öğrenme Yöntemlerinin Depo Yönetim Süreçlerinde Uygulanması: Azure ML Studio Örneği ${ }^{1}$
}

\section{The Application of Machine Learnıng Methods in Warehouse Management Processes: The Example of Azure Ml Studio}

\author{
Cemal ÇELIK, Bandırma Onyedi Eylül Üniversitesi, Türkiye, ccelik@bandirma.edu.tr \\ Orcid No: 0000-0002-4027-3789
}

Nazan YELKİKALAN, Çanakkale Onsekiz Mart Üniversitesi, Türkiye, nyelkikalan@comu.edu.tr

Orcid No: 0000-0002-3321-0237

\begin{abstract}
Öz: E-ticaret süreçleri, lojistik tarafta depo ve operasyon faaliyetleri ile birlikte uyumlu ve eş zamanlı çalışmak zorundadır E-ticaret faaliyetleri; sipariş taleplerinin olumlu bir şekilde sonuçlanması ile gerçekleşen süreçleri içerir. Siparişlerin, doğru ve hıll bir şekilde yönlendirilmesi, depo teknolojilerinin, ERP sistemleriyle entegre ve sorunsuz çözümüne bağlıdır. Bu çalışmanın amacı; gelecekte talep edilecek ürünlerin öngörüsü yapılarak depo kapasitesinin verimli bir şekilde yönetilmesini içerir. Çallşmada, ulusal düzeyde faaliyet gösteren bir E-ticaret firmasının verileri Azure ML(Makine Öğrenmesi) Studio’da işlenerek geleceğe dönük öngörü ve talep tahmin değerleri hesaplanmaya çalışılmıştır. Yeni nesil makine ögrenme bulut platformunun tanıtıldiğl ve model performanslarının karşılaştırmalı olarak ölçümlendiği çalışma; E-ticaret sektörü ve lojistik faaliyetlerin veriler üzerinden planlanması ve geliştirilmesini hedeflemektedir.
\end{abstract}

Anahtar Kelimeler: Depo Yönetimi, ERP, Makine Öğrenmesi

JEL Sinıflandirmast: C45, C55, L81

Abstract: E-commerce processes must work in harmony and simultaneously with warehouse and operation activities on the logistics side. E-commerce activities include the processes resulting in positive order requests. Routing orders in a correct and fast way depends on the integrated and seamless solution of warehouse technologies with ERP systems. The aim of this study is to manage the warehouse capacity efficiently by predicting the products to be demanded in the future. In the study, the data of an e-commerce company operating at national level was processed in Azure ML (Machine Learning) Studio and the future and demand forecast values were tried to be calculated. The study in which the new generation machine learning cloud platform was introduced and model performances were measured comparatively aims to plan and develop ecommerce sector and logistics activities based on data.

Keywords: Warehouse Management, ERP, Machine Learning

JEL Classification: C45, C55, L81

\section{Giriş}

E-ticaret işletmeleri, geleneksel firmalara göre farklı işleyiş ve süreçlere sahip olan teknolojik firmalardır. İş süreçleri; işletme fonksiyonları (finans, pazarlama, insan kaynakları) ve lojistik faaliyetlerden (tedarik, depolama, kargo) oluşmuştur. Yatay ve dikeyde faaliyet gösteren Eticaret firmaları, müşteri taleplerini daha hızlı karşılamak ve müşterilerine sorunsuz bir alışveriş tecrübesi yaşatmak için tedarikçi ve depo hizmet ağlarını etkin bir şekilde yönetmesi gerekir. Depo kaynağına sahip E-ticaret firmaları, hem satıcı hemde tedarikçi rolüne sahiptir.

\footnotetext{
${ }^{1}$ Bu makale Çanakkale Onsekiz Mart Üniversitesi Lisansüstü Eğitim Enstitüsü bünyesinde 2020 yılında tamamlanan "E-Ticaret Örgütlerinde Depo Yönetim Teknolojilerinin ERP Uygulamalarına Entegrasyon Sorunları ve Çözümleri” doktora tezinden derlenerek hazırlanmıştır. 
Ürün sevk işlemleri belli bir operasyon yönetimi ve programı çerçevesinde yürütülür. Hizmet ve ürün yaratma işlevi gören operasyon yönetimi(Stevenson,2015:4);planlama, koordinasyon ve kontrol unsurlarını içerir. Özellikle depo faaliyet süreçlerinin iyileştirmesi, E-ticaret firmalarının maliyetlerini azaltma ve kar marjlarını arttırma konusunda hayati bir önem taşır.

Depolar, e-ticaret firmalarının hayati bir parçasıdır. Yalnızca operasyon yönetimi için değil aynı zamanda müşteri memnuniyeti içinde ihtiyaçtır. Operasyonel yönetim; depo içerisinde ürünlerin kabulü; kodlanıp etiketlenmesi, kategorik olarak elleçlenip ilgili bölüm ve raflara yerleştirilmesi ve gelecek olan taleplere en seri şekilde tepki verilmesi süreçlerini içerir. Teknolojinin sağladığı akıllı otomasyon sistemleri ve araçlar, başarılı bir operasyon ve depo yönetimi işlemlerini kolaylaştıran unsurlardır.

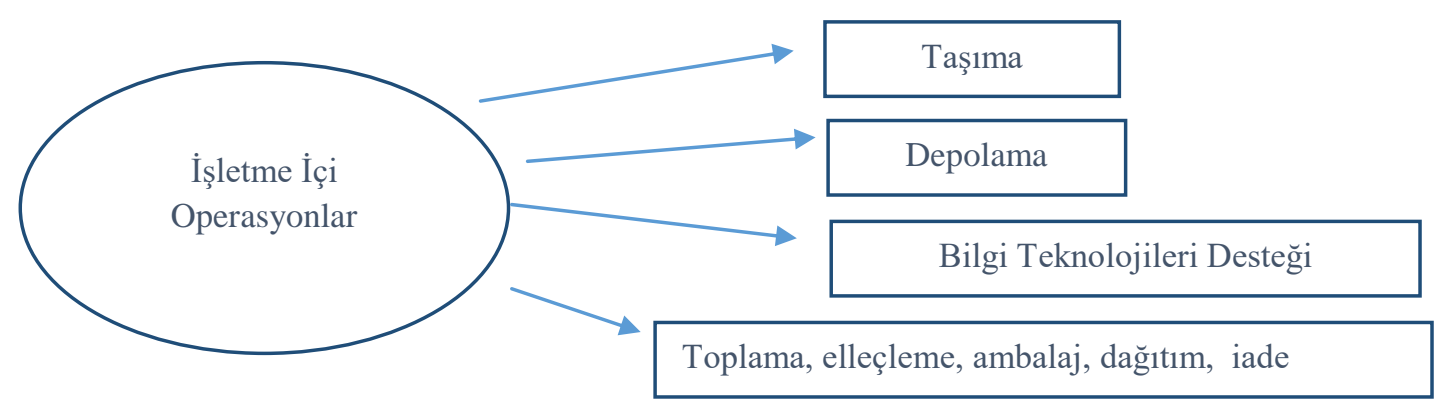

Şekil 1. İşletme İçi Operasyon Faaliyetleri

Kaynak: Lojistik Yönetimi (Çancı ve Erdal,2013:76)

Müşteri odaklı faaliyetlerde hizmet kalitesine katkı sunan depolar, siparişlerin tedarik edilip teslim edilmesi hizmetlerinde sigorta özelliği taşırlar. Ürünlerin muhafaza edilme süresi, maliyet ve verimlilik anlamında firmaları sıkıntıya sokabilir. E-ticaret sektöründe küçük marjlı karlar ile satış yapıldığı için, firmalar açısından finans ve ürün akışının hızlı olması gerekmektedir. Bu nedenle depo ve depolama kararları stratejik kararlar gerektiren süreçlerdir.

\section{E-Ticaret Sektöründe Lojistik Yönetimi}

Lojistik yönetimi; her bir sektör için farklı işlev ve özellikler içeren geniş bir kavramdır. Lojistik yönetim kavramını yazarlar;(Gürdal,2006:11), Tanyaş(2005:5), (Eryürük,2010:10), (Görçün,2017:11) müşteri gereksinimlerini karşılamak amacıyla ürün ve hizmetlere ilişsin, bilgi ve envanterin, üretim yerinden tüketim yerine doğru etkin ve yeterli akışını sağlamaya yönelik; planlama, yürütme ve kontrol etme süreci olarak tanımlamışlardır.

Teknolojik gelişmeler E-ticareti, E-ticaret sektörü de lojistik sektörünün faaliyet alanlarının genişlemesi ve büyümesine katkı sağlamıştır. Sektörde yaşanan hızlı değişim ve 
gelişmeler aşağıdaki konu başlıklarının lojistik faaliyetlere göre uyarlanmasını beraberinde getirmiştir. (Saatçioğlu,2019:6).

- Çok daha fazla müşteriye hizmet

- Küçük ölçekli miktarlarda yoğun talep

- Çok fazla parametre oluşması

- Bilgi ve malzeme akış1

- Malzemeleri ürüne dönüştürme

- Müşterilerden değer oluşturma

E-ticaret firmaları, siparişi oluşturan ürün bileşenlerinin, istenilen adrese teslim ve tahsilatı süresince müşteri, stok ve tersine lojistiğin içinde olduğu bir dizi işlemi planlamak zorundadır. Lojistik süreçleri; taşıma, depolama, dağıtım ve elleçleme gibi adımlarından oluşmuştur. Ürünlerin hızlı ve güvenilir bir şekilde taşınması, E-ticaret sektöründe kritik bir faktördür (Cho vd.,2008:337). Lojistik faaliyet alanlarına; garantili ürün ulaşımı, hızlı teslimat, kapıda ödeme (Slveira,2003:203), müşteri memnuniyeti, sipariş işleme, dağıtım iletişimi, envanter kontrolü, talep tahmini, trafik ve taşıma, depolama, fabrika ve depo yeri seçimi, malzeme işleme, tedarik, parça ve servis desteği, paketleme, artık ve sskartaların elden çıkartılması, geri dönen malların işlenmesi gibi konular girmiştir (Koral,2009:53). Lojistik faaliyetler temelde fiziksel faaliyetler olarak algılanmasına rağmen, malzemeleri değere dönüştürerek, firma ve müşteriler için yeni değerler oluşturulmasını sağlar. Özelikle, depolama faaliyeti katma değer yaratarak E-ticaret firmalarının rekabet avantajı yaratmasını sağlamış olur. (Küçük,2017:288).

\subsection{Depo Ve Depo Yönetimi Kavramı}

Depolar; ürünlerin kapalı ve açık yerlerde stok ve muhafaza edilerek korunduğu, tedarik ve dağıtım operasyonlarının gerçekleştirildiği yerlerdir. E-ticaret depolarını Çancı ve Erdal (2013:100), (Perrealt ve McCarthy,1996:72), dağıtım merkezi olarak tanımlayarak, genel işletme depolarından; müşteri siparişlerine göre, hızlı, sürekli ve kapsamlı sevkiyatlara elverişli büyük hacimli depolar olarak ayırt etmişlerdir. Depolar, ürünleri tedarik kaynaklarından teslim alan, ayrımını yapan, kayıtlarını tutan, muhafaza ve bakımı ile siparişe uygun olarak dağıtımını sağlayan tesislerdir

Depo yönetimi; ürünlerin izlenmesi, müteakip depolama ve kar getiren ürünlerin koordinasyon süreçleri olup, sonunda ürünlerin doğru yerlere dağıtımıdır (Harper,2010:5). Mal kabul sonrası; hammadde, yarı mamul ve ürünlerin belirli bir sistem içerisinde planlı ve organize bir biçimde elleçlenip, istifleme ve sevkiyat işlemlerinin yanı sıra, ayırma, birleştirme, konsolidasyon, etiketleme, paketleme, paletleme ve bu türde çok sayıda lojistik aktivitenin gerçekleştirilmesi potansiyeline sahip olan yerlerdir (Görçün,2017:11). 
Temel lojistik faaliyetlerinden biri olan depo yönetimi, mal ve sipariş akışında önemli bir yere sahiptir. Depo yönetimi; doğru ürününün, özellik ve kalitesinin bozulmadan istenilen yere, istenilen zamanda teslim edilmesine operasyonel olarak katkı sağlayan faaliyetlerdir. Güncel teknolojiler ile donatılmış depo birimleri, operasyonel yeteneği vasıtasıyla ürün ve hizmetlere değer katan ve rekabet edebilme gereksinimlerini ortaya çıkaran kaynaklardır (Qureshi ve Kretzer, 2012:51).

\subsection{E-Ticaret Sektöründe Depo Yönetim Süreçleri}

E-ticaret sektöründe müşteri siparişleri rastsal özellikler taşır. Yüz binlerce siparişin aralıklı zamanlarda rastgele olarak alındığı ve sevkiyata hazırlandığı süreçleri içerir. Bu yüzden Eticaret sektöründe mevcut depoların tasarım ve dizaynı, E-ticaret ölçeklerini (yoğunluk, çeşitlilik, hız, doğru sevkiyat) karşılayacak şekilde tasarlanmalı ve dizayn edilmelidir (Koster vd.,2017:6327). Depo yönetimi süreçleri, hemen hemen tüm sektörlerde benzer faaliyet ve fonksiyonlara sahip olmasına rağmen, E-ticaret sektörü için; sipariş yoğunluğu, ürün çeşitliliği, ebat farklılıkları, paketleme ve kargolama süreçlerinin yer aldığı karmaşık ve hız gerektiren süreçleri içerir. E-ticaret ile ilgili, depo süreçlerinin daha iyi anlaşılması için Hepsiburada firmasının depoda gerçekleşen tüm operasyonel süreçleri aşağıdaki linkte aktarılmaya çalışılmıştır.

https://www.youtube.com/watch?v=DtF1GMxybhc (Erişim Tarihi :30:12:2019)

E-ticaret depo operasyonları, fonksiyonları veya süreçleri aşağıdaki başlıklarda sıralanmıştır (Hompel ve Schmidt,2014:20) (Çancı ve Erdal,2013:101).

- Mal Kabul İşlemleri

- Kalite Kontrol -Yerleştirme ya da istifleme

- Sipariş Toplama

- Ambalajlama

- Sevkiyat

Depo yönetim süreçleri; mal kabul, yerleştirme, toplama ve sevkiyat şeklinde ifade edilebilir. Basit görünen bu faaliyetler; zaman, hizmet kalitesi ve maliyetle ilgili dış etmenler sebebiyle karmaşık bir hal alır, bu nedenle sürekli kontrol edilerek en verimli hale getirilmesi gerekir (Hompel ve Schmidt,2014:4) . Hompel ve Schmidt karmaşıklık sebeplerini aşağıdaki gibi sıralamaktadir:

- Mal kabulü planlanamamakta ya da mallar düzensiz aralıklarla gelmektedir.

- Farklı kategoride yer alan ürünler için, ayrı taşıma, depolama veya elleçleme teknolojileri gerekebilir.

- Sürekli değişen ürün akışı ve sipariş yapısı söz konusudur. 
Depo faaliyetlerinin iş akış şemasına göre tasarımı aşağıdaki şekilde dizayn edilerek sürecin nasıl işlendiği şekil ile anlatılmaya çalışılmıştır.

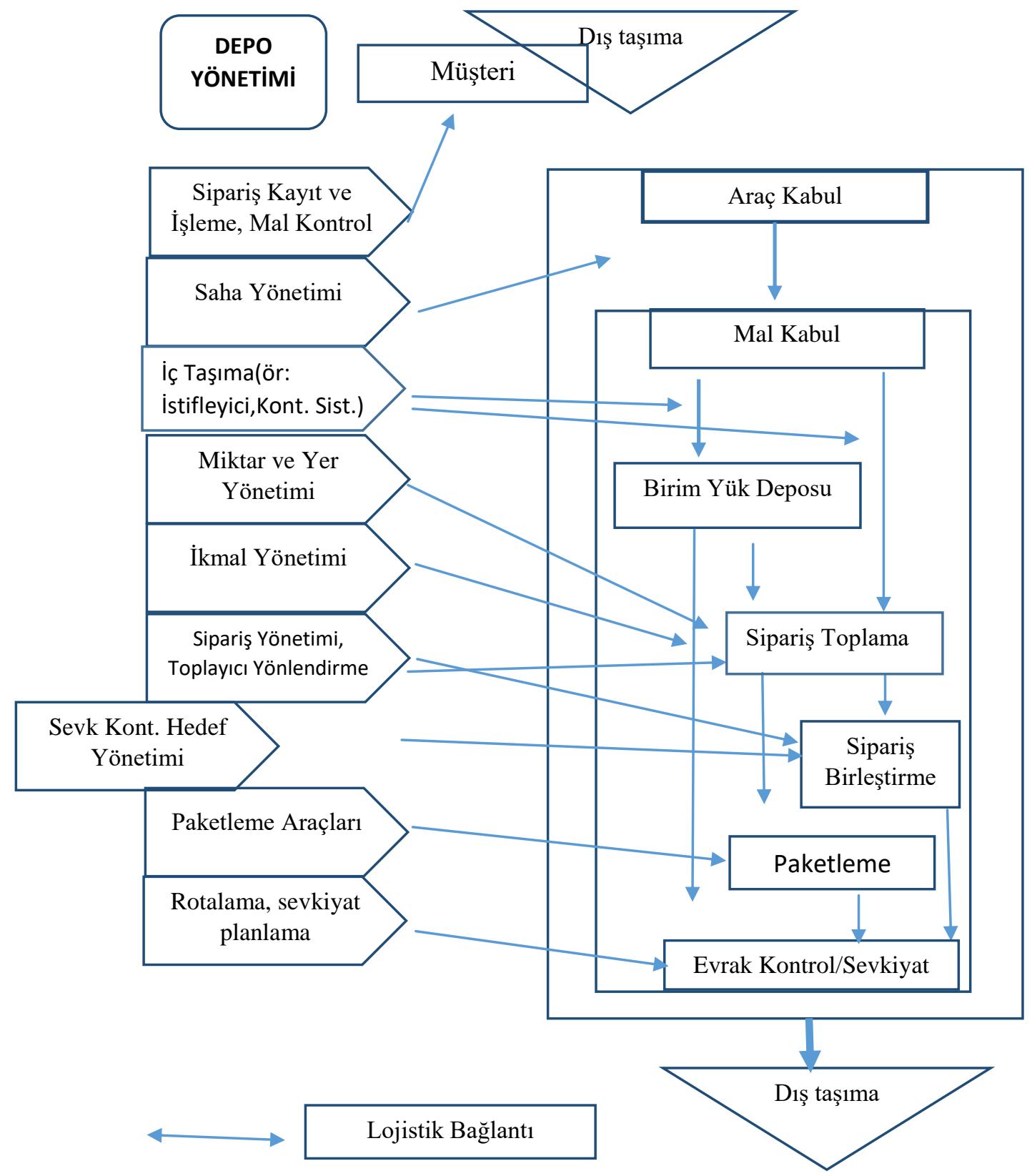

Şekil 2. Depo Yönetim Sistemlerinin Temel Öğeleri

Kaynak: Hompel ve Schmidt-Warehouse Management-2014::21). Çev: Tanyaş ve Düzgün

Depo sistemleri Şekil 2'de anlatılmış olan farklı ımodüllerle genişletilmiş olsa bile depo faaliyetleri dört temel işlev üzerine kuruludur. Bunlar teslim alma, stoklama, sipariş toplama ve sevkiyat işlemleridir. Şekilde yer alan işlemler teknolojik yazılım üzerinde kurgulanmış süreçlerden oluşmaktadır. Verilerin anlamlı hale getirilip bilgiye dönüşmesi depo yönetim sistemlerinin lojistik faaliyetlerin etkin ve verimli bir şekilde yürütülmesini sağlar. 
Depo'ya yerleştirilecek olan ürünlerin, optimize yerleşimi ve sonrasında hızlı bir şekilde toplanmasına yönelik bir çok algoritmik (Cecconi vd.,2012:135), (Berg ve Zijm,199:520), (Chan ve Chan,2011:2688) çalışma yapılmıştır. Hompel ve Schmisdt (2014:28) yerleştirme yöntemlerini; "statik depolama, rassal depolama, bölgesel, çapraz dağıtım, kümeleme, en kısa yol ve ön depolama" başlıkları altında toplamıştır. Toplama yöntemlerini ise ; FIFFO, LIFO, miktar uyarlama, tam olmayan birim yük, en kısa yol, en az koridor, tur bazlı, zaman bazlı, ileri depolama" olarak açıklamıştır. Toplama performansını yükseltmek ve toplayıcı hatalarını azaltmak için doğru bilgi akışı çok önemlidir. Hatalı toplama süreci, müşteri memnuniyetsizliğinin yanında, E-ticaret firmaları için oldukça maliyet getirici ve iş devri yaratan süreçlerdir. Bunu azaltmak için, ürünlere yönelik anahtar veri tanımlama yapılarak, sürecin hızlı ve doğru bir şekilde gerçekleştirilmesi sağlanır.

\section{Talep Tahmin Konusu}

Ürün stoklarının optimize bir şekilde yönetilmesi, satış ve depo operasyonların planlanması gibi geleceğe dönük öngörü faaliyetleri talep tahmin çalışmalarının konuları arasına girer. Eticaret firmalarında anlık olarak oluşan milyonlarca verinin, doğru bir yöntemle işlenerek anlamlandırılması, stoktan depolamaya kadar bir dizi süreçlerin verimli bir şekilde yönetilmesini sağlar. Doğru talep tahmini ile müşteri memnuniyeti arttırılmakta, stok fazlalığ1 azaltılmakta, üretim ve satın alma faaliyetleri daha etkili hale gelmekte, taşıma faaliyetleri daha iyi organize edilmekte ve bu sayede maliyetler azaltılmaktadır (Saatçioğlu,2016:1)

Tahmin yöntemlerini Saatçioğlu (2016:5) ve Akyurt (2015:148) iki başlık altında açıklamaya çalışmışlardır. Bu yöntemler; “deneyimli yöneticilerin sezgi yetenekleri ve nicel yöntemler dediğimiz geçmişe ya da bugüne ait bazı bilgileri alıp bunları bazı matematiksel modeller yardımıyla geleceğe uyarlama olarak" bildirmişlerdir. E-ticaret sektöründe yer alan işletmeler, müşteri analitiklerini yaptırarak, onların taleplerini tahmin etmeyi ve ona göre stok bulundurmayı hedeflerler. Firmaların, satın alma, satış ve iş geliştirme bölümleri ayrı ayrı tahminler yaparak geleceğe dönük planlamalar yaparlar (Stevenson, 2015: 69). E-ticaret firmalarının, tedarik zinciri boyunca, tüm noktalarda erişim esnekliği ve kapasiteleri anlama ihtiyacı vardır. Süreçlerle ilgili, talep edilen tahmini değerlerin tüm paydaşlarla paylaşılması gerektiğinin önemi sürdürülebilir bir büyüme ve rekabet çerçevesi içinde ele alınmıştır (Croxton ve Rogers:2001:19). 


\section{Azure Makine Öğrenme Platformu}

Azure ML(Machine Learning) Studio; Microsoft firmasının geliştirdiği bulut üzerinde çalışan yapay zeka ve makine öğrenmesi servisleri sunan ortak bir platformdur. Azure ML platformunda E-ticaret sektörü için ürün önerme, kümeleme ve tahmin önerileri gibi uygulama modelleri geliştirilebilir. Azure ML mevcut ve farklı makine öğrenme modellerinden, derin öğrenmeye kadar her türlü makine öğreniminde kullanılabilen, birden fazla veri dosyası üzerinde çalışma esnekliği sağlayan esnek bir platformdur. Azure ML; esnek yapısıyla; Python, C\#, R ve Java gibi yazılım dilleri kullanılarak makine öğrenim modelleri oluşturup, geliştirme araçları ile modelleri eğitebilir ve çıktılarını paylaşabilirsiniz (Coolliler ve Shahan,2016:243).

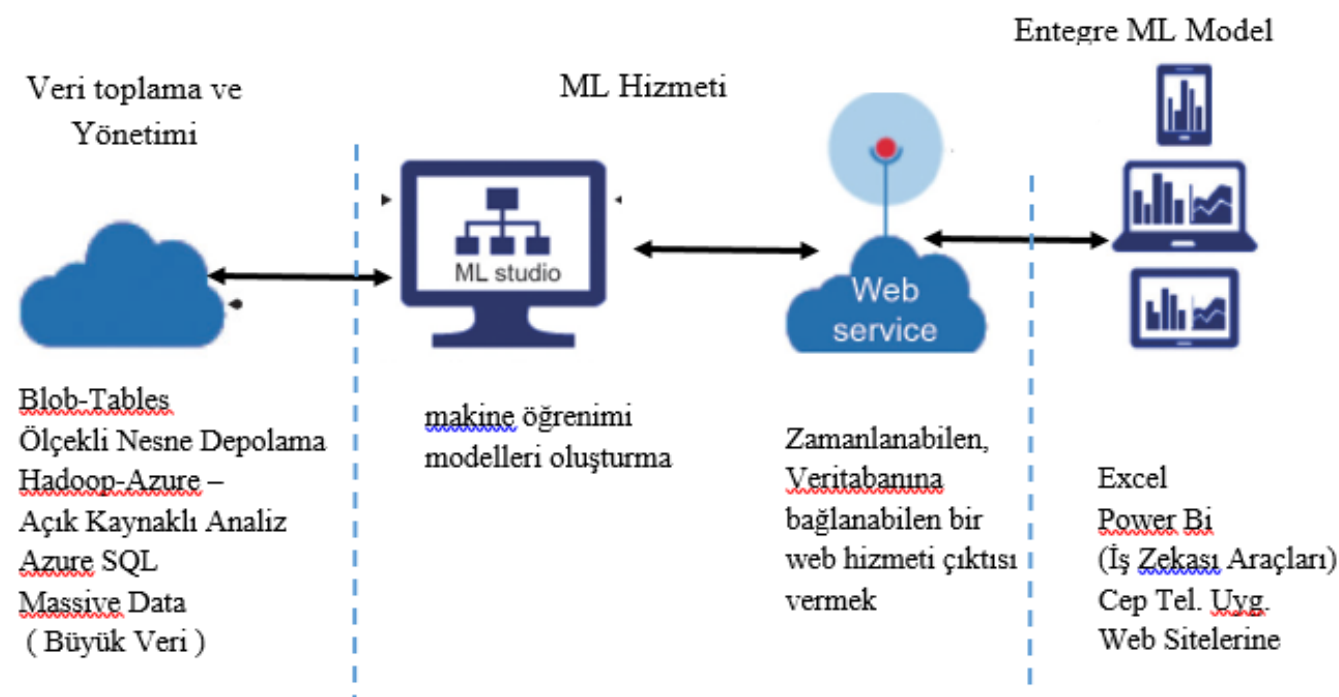

Şekil 3. Azure ML(Machine Learning) Studio Modeli

Kaynak: Yubao Chen-Integrated and Intelligent Manufacturing: Perspectives and Enablers (2017-594)

Şekil 3'de AZURE ML Studio'nun çalışma mimarisi gözükmektedir. İlk süreç verilerin toplanması ve yönetimi aşamasıdır. Veri setleri dışardan platforma yüklenilebildiği gibi ayrıca firma kendi faaliyetleri için kullandıkları tüm ticari uygulamaları AZURE bulut ortamına taşıyıp online bir şekilde kullanabilir. Sürecin devamında, platform içindeki model geliştirme araçları ya da yazılım programlama dilleri kullanılarak, veri setlerinin işlenmesini sağlayan modeller oluşturulur. Makine modelleri tarafından işlenen verilerin çıktıları ara programlar ve web servisleri aracılığıyla entegre yazılım programlarına (Web sayfalarına, Excel, Power BIİş zekası-) gönderilerek karar destek süreçlerine katkıda bulunmayı sağlar. 


\section{Ampirik Uygulama}

E-ticaret örgütlerindeki lojistik süreçlerin bilişim teknolojileriyle birlikte ele alındığ çalışmanın uygulama kısmında, lojistik tarafta yer alan depo yönetiminin etkin ve verimli kullanımına yönelik bulut çözümlerinde yer alan makine öğrenmesi ve yapay zeka modelleri kullanılarak en yakın tahmin sonuçları elde edilmeye çalışılmıştır.

\subsection{Uygulamanın Yöntemi}

Entegre bulut yazılım modülü uygulamasında kullanılacak olan yöntemin kapsamında aşağıdaki akış adımları kullanılmıştır.

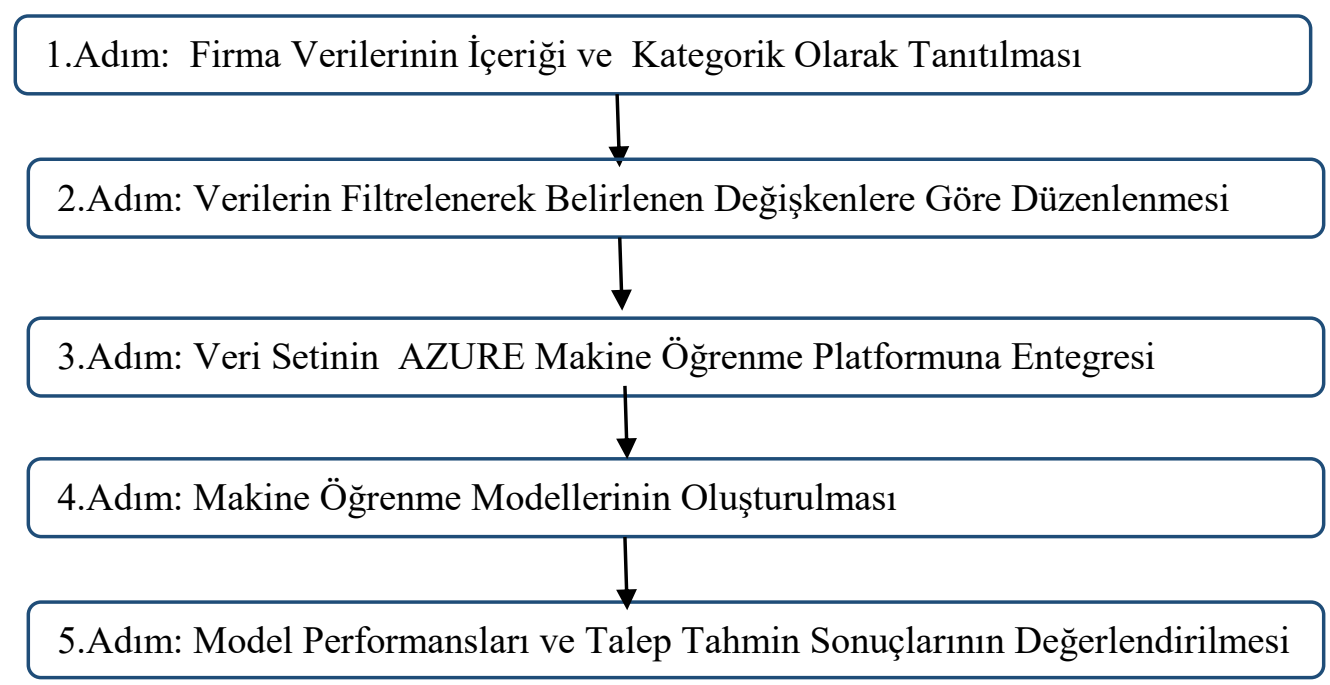

Şekil 4. Entegre Bulut Yazılım Uygulaması İş Akış Şeması

1.Adım: Entegre Bulut Yazılım Uygulamasında kullanılacak firma verileri Tablo 1 de kategorik olarak sıralanmıştır. E-ticaret firması ulusal düzeyde faaliyet göstermekte olup, daha çok dikey alanda ev eşyaları ve mobilya türünde çalışmaktadır Firma; aşağıdaki kategorilere göre satış yapmakta ve siparişleri tedarikçilerden veya kendi sahip olduğu depolardan karşılamaktadır.

Tablo 1. Ürün Kategori Tablosu

\begin{tabular}{|c|l|}
\hline Sıra No & Departman \\
\hline 1 & Anne \& Bebek \\
\hline 2 & Aydınlatma \\
\hline 3 & Banyo \\
\hline 4 & Bijuteri ve Saat \\
\hline 5 & Elektrikli Ev Aletleri \\
\hline 6 & Ev Dekorasyon \\
\hline 7 & Ev Tekstili ve Yaşam \\
\hline 8 & Kozmetik \& Kişisel Bakım \\
\hline 9 & Mobilya \\
\hline
\end{tabular}




\begin{tabular}{|l|l|}
\hline 10 & Mutfak \\
\hline 11 & Outlet \\
\hline 12 & Spor \& Outdoor \\
\hline 13 & Tamamlayıcı Mobilya \\
\hline 14 & Yapı Market - Bahçe \\
\hline
\end{tabular}

2. Adım: Verilerin Filtrelenerek Belirlenen Değişkenlere Göre Düzenlenmesi

Yaklaşık 250.000 satırdan oluşan firma verilerinden Aydınlatma, Banyo ve mobilya kategorilerindeki bazı markaların ürünleri filtrelenmiş (süzülmüş) ve seçilmiştir. 250.000 satırdan oluşan ham verilerden kategori, alt kategori, marka, yıl, ay, adet, fiyat ve tutar değişken alanları seçilerek, uygulama alanında kullanılması için Excel programında CSV (virgülle ayrılmış değişken) formatına çevrilmiştir.

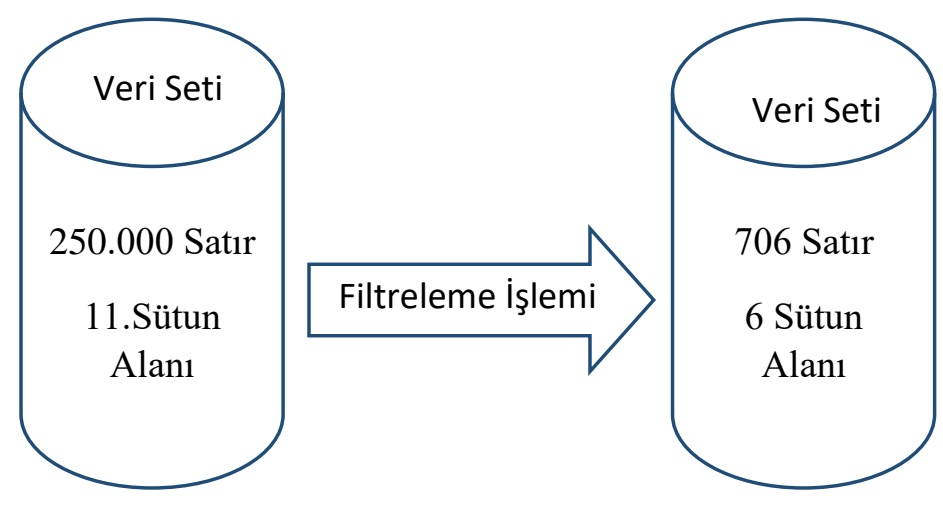

Şekil 5. Veri Setinin Filtrelenip - Düzenlenmesi

Filtrelenmiş verilere ilişkin bilgiler Şekil 5 de olduğu gibi örneğin veri seti (data set) 250.000 satır, 11 sütundan oluşan veri, 706 satır 6 sütun alanına indirgenmiştir.

3.Adım: Veri Setinin AZURE ML(Machine Learning Studio) Makine Öğrenme Platformuna Entegresi: Bu uygulamada Dataset kısmına Excel de hazırlanmış olan veriler CSV formatında dışardan yüklenmiştir.

4. Adım: Azure ML Studio ortamına aşağıdaki adres linkine tıkladıktan sonra, gerekli kimlik bilgileri sorgulaması ile girebilirsiniz.

\section{https://studio.azureml.net/}

5. Adım: Oluşturulan modellerin hesaplama sonuçları ve performansları değerlendirilmiştir. Bu tür çalışmalar için model performanslarının belirlenmesinde sık olarak kullanılan mutlak hata oranları hesaplaması (MAPE), ortalama kare hatası (MSE) ve hata kareleri ortalamasının karekökü (RMSE) kullanılmıştır. Model hesaplama sonuçlarında 
MAPE değerlerinden en küçük olanı, MSE ve RMSE değerlerinde ise sıfıra yakın olan değerler alınmıştır.

\subsection{Uygulamanin Modelleri}

Makine öğrenme yöntemleri içerisinde yer alan; regresyon modelleri karşılaştırılarak, geleceğe dönük en iyi tahmin modelinin oluşturulması hedeflenmiştir. Modellerin; veriler üzerindeki performans Metrics'lerinin (ölçüm değerleri) sonuçları; model içerisinde hazırlanan tablo ve grafiklerle açıklanmaya çalışılmıştır. Model içerisinde R-Script,, SQL gibi yardımcı konteyner geliştirme araçları ile modele yazılım kodları eklenerek modelin etkinliği arttırılmaya çalışılmıştır.

\subsection{Makine Öğrenmesinde Regresyon Modelleri}

Kurulan model ağacında; makine öğrenme modellerinden; Arttırılmış Karar Ağacı Regresyon (Boosted Decision Tree Regression), Doğrusal Regresyon (Lineer) ve Yapay Sinir Ağları (Neural Network Regression) algoritmaları karşılaştırmalı olarak değerlendirilmiştir.

Regresyon modelleri sürekli bir tepki öngörmeye çalışır. Bu, tepkinin bir dizi sonsuz değer alabileceği anlamına gelir (Kakade vd.,2018:209). Doğrusal regresyon; tahminlerde bulunmak ve verileri analiz etmek için kullanılan bir modelleme tekniğidir (Tranmer vd,2020:3). Makalesinde Goia vd.(2010:702),'Lineer regresyon fonksiyon uygulamas1, yeni ürünlerin pazar tüketimini tahmin etmede ve standart olan diğer yöntemlerle karşılaştırıldığında, fonksiyon tekniğinin avantajlı olduğu görünmektedir”, ifadesiyle regresyon modelinin öneminden bahsetmiştir. Regresyon analizi, değişkenler arasındaki ilişkiyi ve doğrusallık kavramını kullanarak tahmin eşitliği geliştirir. Değişkenler arasındaki ilişki belirlendikten sonra bağımsız değişkenlerin değerleri bilindiğinde, bağımlı değişkenin değeri tahmin edilebilir.

Regresyonda değişkenler, bağımlı değişken ve bağımsız değişken olarak irdelenir ve bağımlı değişken, bağımsız değişkenler ile ilişkilendirilerek açıklanmaya çalışılır (Arslan ve Bayırtepe,2018:46). Karşılaştırılan modeller içinde; YSA (Neural Network Regression) için makalesinde Chenn ve Wang;(2007:216), "Geleceğin tahmin modellemelerinde yapay sinir ağlarının başarılı işler yaptı̆̆ını”, dile getirmişlerdir. Ayrıca yazarlar; geleneksel istatistik modellerinin aksine, YSA 'da verilerin birbiriyle haberleştiğinin önemine vurgu yapmışlardır.

Yapay sinir algoritmalarını geliştiren Vapnik(1995); yapıyı geliştirerek; destek vektör makineleri olarak isimlendirmiştir. Destek vektör makineleri akademik alanlarda sınırlı olsa da, doğrusal olmayan regresyon çözümlerinde oldukça başarılı bir görüntü ortaya çıkartmıştır. 
YSA; esneklik, uyum ve farklı tahmin yeteneği ile oldukça tercih edilen bir modeldir. YSA'nın; yüz tanıma, varlık hareketi ve anormalin tespiti gibi farklılıkları vardır. Ayrıca; denetimli öğrenme, denetimsiz öğrenme ve pekiştirmeli öğrenme algoritmaları ile farklı çözümleri beraberinde getiren becerilere sahiptir (Kakade vd.,2018:315). Arttırılmış Karar Ağacı Regresyon (Boosted Decision Tree Regression) modeli metrics(ölçümler) için sık olarak başvurulan modellerden birisidir. BTR(Boosted Decision Tree Regression), uygulamalarda bir çok performansın içinde daha iyi performans elde etme amacı güder. Daha iyi bir tahmin için birkaç modelin bir araya getirilmesi ile oluşan tekli bir model yapısı taşır. BTR; hem istatistik hemde ML(Machine Learning) teknikleri ve öngörülerini kullanan popüler bir yöntemdir (Elith vd.,2008:805). BTR; yaklaşım olarak geleneksel regresyonlardan farklıdır. Öngörü tahminlerini optimize etmek için arttırılabilen basit karar ağaçlarının uygulamalarını tercih eder (Graham,2006:134)

\subsection{Modelin Kurulumu}

Azure ML Studio ortamına https://studio.azureml.net/ adresinden girdikten sonra karşınıza aşağıdaki ara yüz gelecektir.

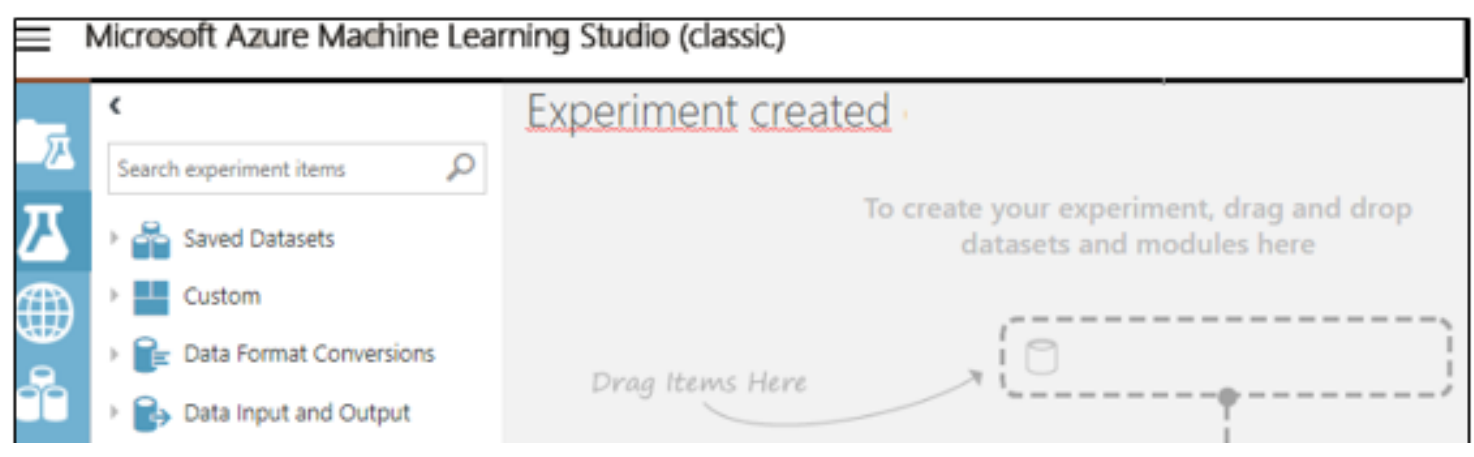

Şekil 6. Model Oluşturma ve Çalıştırma Ara Yüzü

Şekil 6'da yer alan ekran görüntüsü, Azure ML platformunda her türlü modelin kurulduğu ve çalıştırıldığı ara yüzdür. Sol tarafta yer alan model geliştirme araçları kullanılarak, uygulamada kullanılacak olan tekli regresyon model ağacı Şekil 7 de ki gibi hazırlanmış olunur. Model ağacında yer alan her bir konteyner bir diğerine oklar ile bağlanarak modelin akışı sağlanmış olur. 


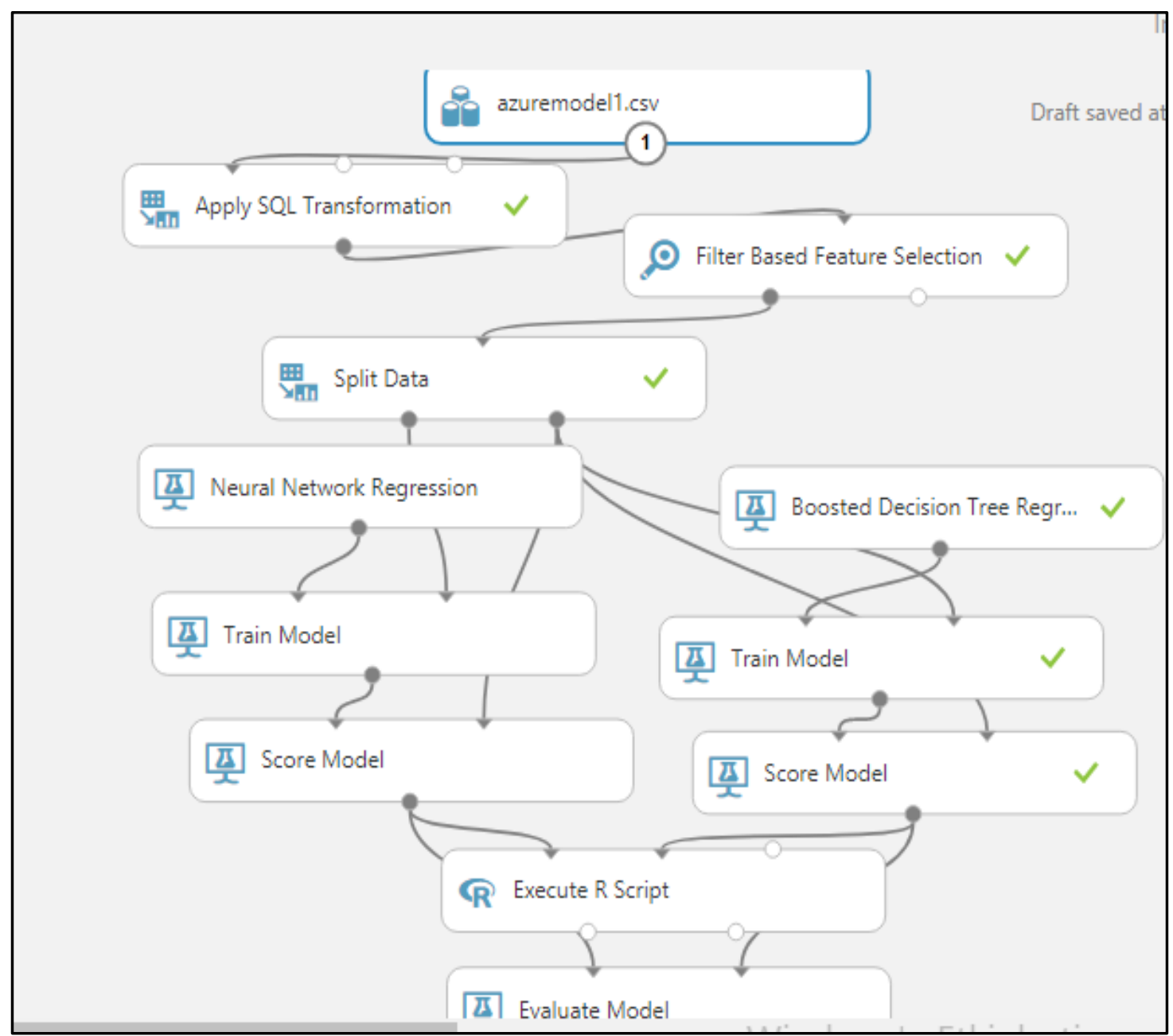

Şekil 7. Tekli Regresyon Model Ağaç Yapısı

Şekil 7 de yer alan görsel, uygulama için kurduğumuz ilk model ağacı örneğidir. Azuremodel1 isimli dosyada yer alan veri seti, sisteme yüklendikten sonra belli bir işleve sahip dikdörtgen konteynerlerin aşağı yöne doğru iş akış okları ile birbirine bağlanarak belli bir amacın gerçekleştirilmesi hedeflenir. İstenirse ikili ve çoklu sınıflandırma modelleri de aynı yöntemle oluşturulabilir. Her bir dikdörtgen konteynerin farklı bir fonksiyon işlevi vardır. Bu işlevi yerine getirebilmesi için aşağıdaki gibi Run Selected menü seçeneği ile çalıştırılması ve hata vermemesi gerekir.

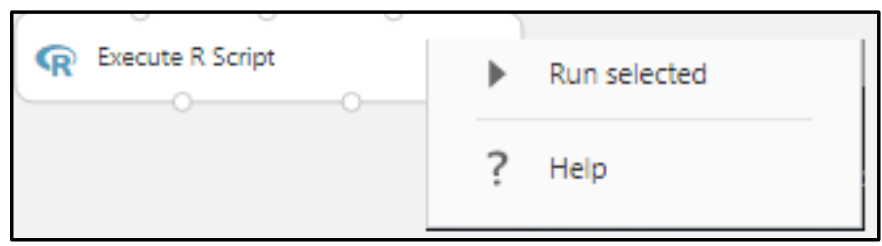

Şekil 8. .Konteyner Çalıştırılması 
Azure ML Studio'da tüm adımlar tek bir seferde ya da Şekil 8 de olduğu gibi adım adım çalıştırılarak, her bir konteynerin (akış şeması) üst kısmında (OK- $\checkmark$ ) işareti ile onaylanması gerekir. Onaylanmayan konteyner olursa, o işlev kullanılamadığı için modelin çalışması durmuş olur

\subsection{Ampirik Bulgular}

Modelde kullanılan her bir konteyner aracının ayrı bir işlevi vardır. 3. Adımda yer alan Filter Based Feature Selection (Filtre Tabanlı Özellik Seçici) araç kutusunun amac1, adet değişkenini etkileyen, bağımsız değişsenleri belirlemektir. Makine algoritmalarının belirlediği değişkenler dikkate alınarak, bekleme ve işleme süreleri azaltılıp kaynakların etkin bir şekilde yönetilmesi sağlanır.
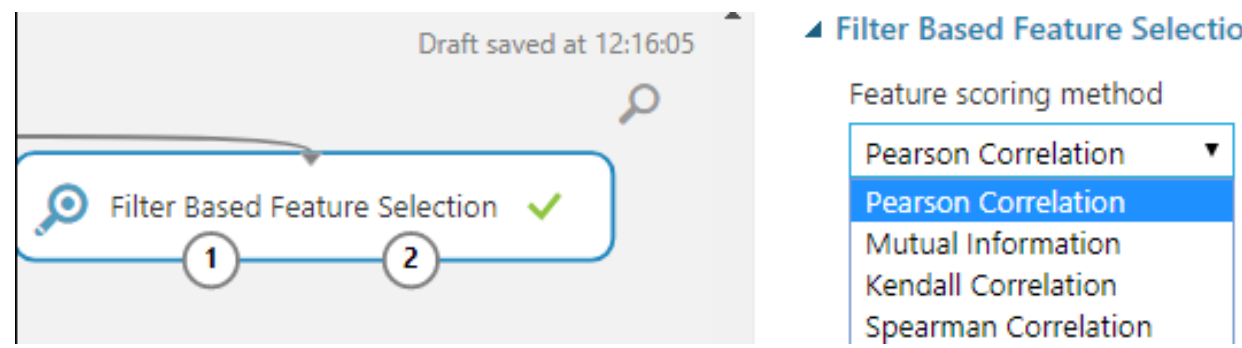

Şekil 9. Filtre Tabanlı Özellik Seçimi

Şekil 9' da adet miktarını etkileyecek olan değişkenlerin tespiti için kullanılacak olan korelasyon metodlarının listelenmiş olduğunu görürsünüz. Veri biliminde kullanılan Pearson, Kendall ve Sperman korelasyon çeşitleri için Hauke ve Kossowski (2011:87),”en popüler korelasyon çeşitleri olarak" vurgu yapmıştır. Değişkenler arasında, Pearson; doğrusal ilişskiyi, Sperman; monotomik ilişkiyi, Kendall ise değişkenler arasındaki uyumu ölçmeyi sağlar.

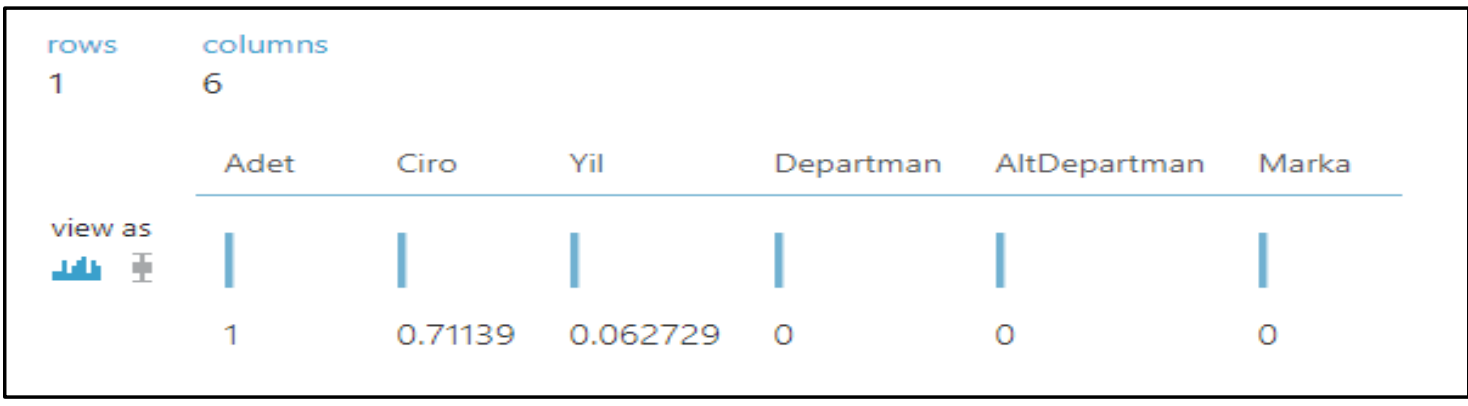

Şekil 10. Kendall Metodu Sonuçları 


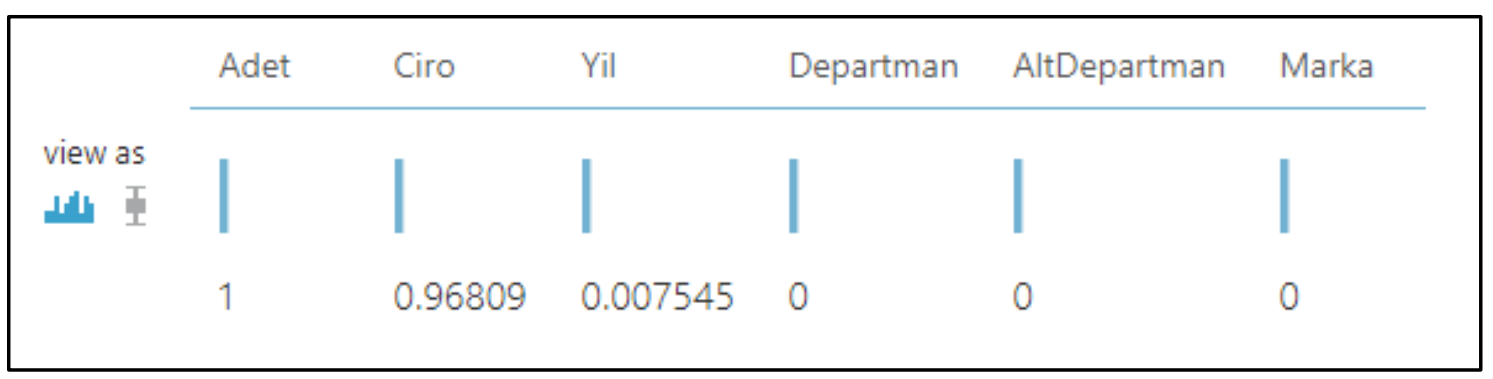

Şekil 11. Pearson Metodu Sonuçları

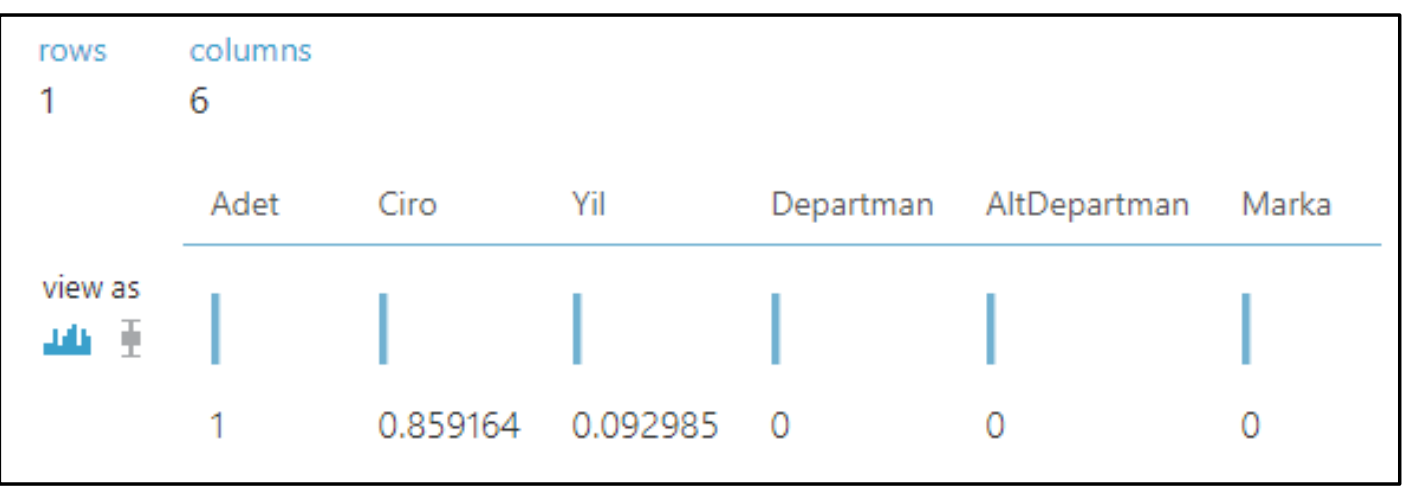

Şekil 12. Spearman Metodu Sonuçları

\subsection{Verilerin Filtrelenmesi}

İkinci satırda yer alan SQL Query Script'lerini kullanarak aşağıda yer alan SQL yazılım kodları ile ürünlerin alt departmana göre sınıflandırılarak işlenmesi sağlanmaktadır. Veriler bu sınıflandırmaya göre eğitim ve test verisi olarak ayrılmaktadır.

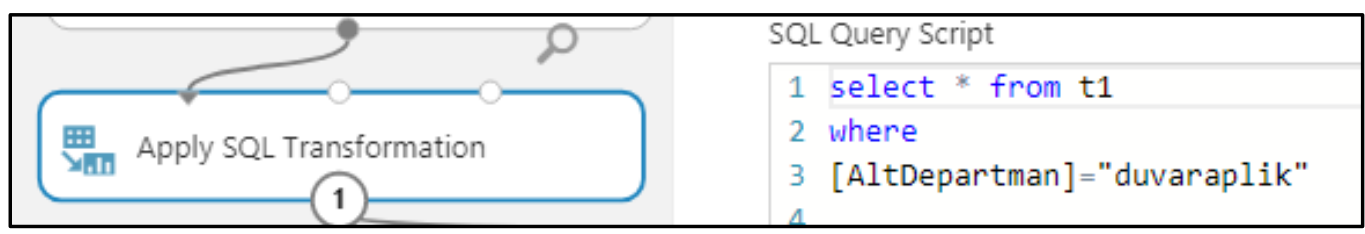

Şekil 13. SQL Komut Uygulaması

\section{7. Ĕgitim ve Test Verisinin Ayrılması}

Split data seçeneğini seçip özellikler kısmında eğitim ve test verilerinin ayarlaması yapılarak model eğitimi için gerekli verilerin temini sağlanmış olur.

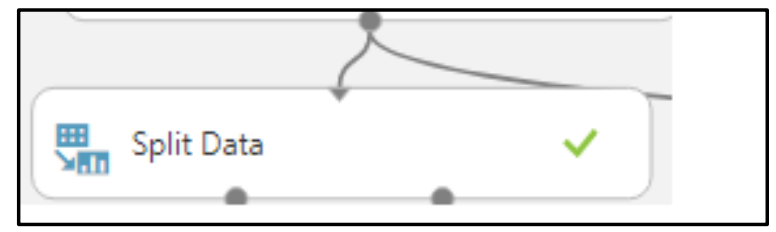

Şekil 14. Verilerin Bölümlenmesi

Verilerin bölünme seçenekleri Şekil 15' deki kısımdan belirlenmiş olur. 


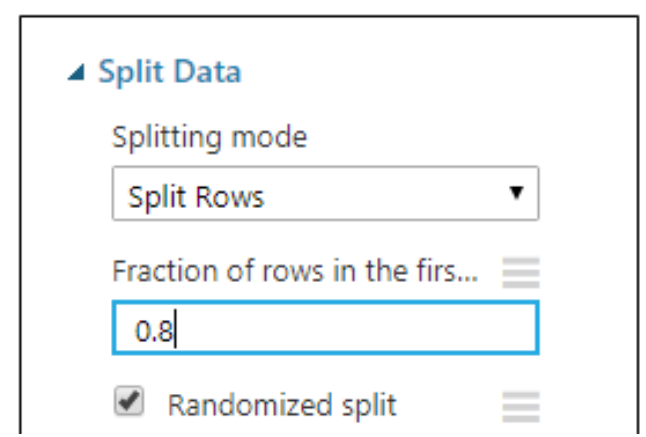

Şekil 15. Verilerin Bölümlenme Değerleri

Şekil 15 de verilerin \% 80'i seçilecek olan modelde eğitilmesi için , kalan \%20 lik kısmı ise test verisi olarak kullanılarak geleceğe dönük tahminlerde gerçeğe yakın değerlerin elde edilmesi sağlanmaya çalışılır.

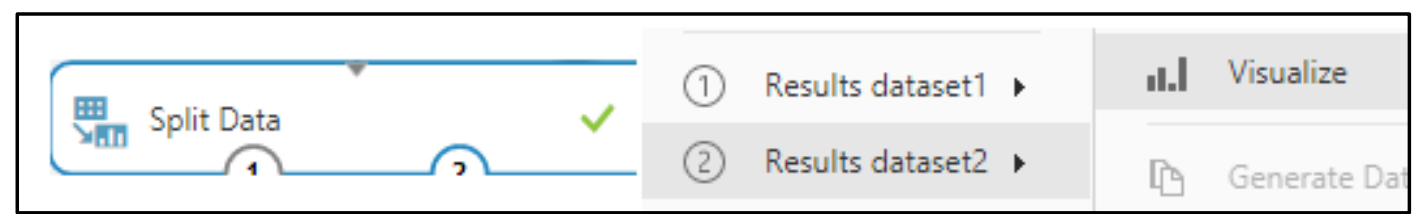

Şekil 16. Eğitim ve Test İçin Ayrılan Verilerin Görülmesi

Şekil 16 da Split Data üzerinde sağ tuş (Results dataset1-Visualize ) ikonlarının üzerine geldiğinizde Şekil 17 ve 18 de 120 satır ve 4 sütunu modelin eğitimi için . (Result data set2 -Visualize) ikonları ise 30 satır ve 4 sütunun test verisi için ayrıldığını görürsünüz.

\begin{tabular}{|ll|}
\hline rows & columns \\
120 & 4 \\
\hline
\end{tabular}

Şekil 17. Model Eğitimi Veri Seti

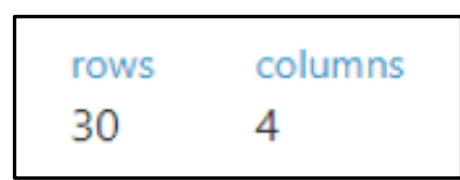

Şekil 18. Test İçin Ayrilan Veri Seti

\subsection{Verilerin Farklı Regresyon ve Yapay Sinir Ăg Modellerinde İşlenmesi}

Regresyon modelleri çalıştırıldıktan sonra, karşılaştırma sonuçlarını; Şekil 19 daki Score Model araç butonunun üzerinde sağ tuşa tıklayarak görselleştirebilirsiniz.

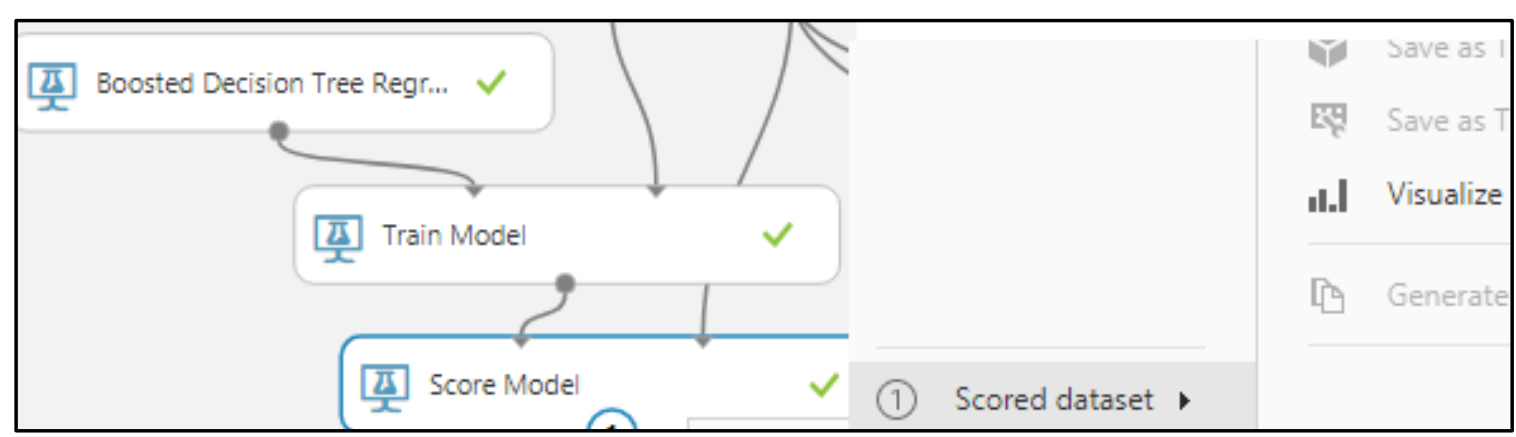

Şekil 19. Model Sonuçları Görüntü İşlemi 
Firmanın gerçekleşen adet değerleri ile, modelin gerçekleştirdiği Scored Labels sütunundaki tahmini adet değerlerinin birbirine çok yakın olduğu gözükmektedir.

\begin{tabular}{|c|c|c|c|c|c|c|}
\hline Departman & AltDepartman & Marka & Yil & Adet & Ciro & $\begin{array}{l}\text { Scored } \\
\text { Labels }\end{array}$ \\
\hline & & In & $\left.||||\right|_{\text {IIII }}$ & $\|_{\text {|. }}$ & & .||. \\
\hline Aydinlatma & duvaraplik & D-Light & $\begin{array}{l}\text { 2017-02- } \\
\text { 01T00:00:00 }\end{array}$ & 21 & 568 & 23.309307 \\
\hline Aydinlatma & duvaraplik & $\begin{array}{l}\text { Avize } \\
\text { Marketim }\end{array}$ & $\begin{array}{l}\text { 2018-05- } \\
\text { 01T00:00:00 }\end{array}$ & 8 & 661 & 7.683287 \\
\hline
\end{tabular}

Şekil 20. BTR-Arttırılmış Karar Ağacı Regresyon (Boosted Tree Regression)

Model Tahmini Sonuçları

\begin{tabular}{|c|c|c|c|c|c|c|}
\hline Departman & AltDepartman & Marka & Yil & Adet & Ciro & $\begin{array}{l}\text { Scored } \\
\text { Labels }\end{array}$ \\
\hline & & n & $\left.||||\right|_{\text {IIII }}$ & $\|_{\text {|. }}$ & & \\
\hline Aydinlatma & duvaraplik & D-Light & $\begin{array}{l}\text { 2017-02- } \\
\text { 01T00:00:00 }\end{array}$ & 21 & 568 & $21.57907^{t}$ \\
\hline Aydinlatma & duvaraplik & $\begin{array}{l}\text { Avize } \\
\text { Marketim }\end{array}$ & $\begin{array}{l}\text { 2018-05- } \\
\text { 01T00:00:00 }\end{array}$ & 8 & 661 & 7.337849 \\
\hline
\end{tabular}

Şekil 21. YSA-Yapay Sinir Ağları (Neural Network Regression) Modeli Tahmini Sonuçları

\begin{tabular}{|c|c|c|c|c|c|c|}
\hline Departman & AltDepartman & Marka & Yil & Adet & Ciro & $\begin{array}{l}\text { Scored } \\
\text { Labels }\end{array}$ \\
\hline & & ШШ & ||||||||ІІ & $\|_{\text {|. }}$ & & |ll.. .... \\
\hline Aydinlatma & duvaraplik & D-Light & $\begin{array}{l}\text { 2017-02- } \\
\text { 01T00:00:00 }\end{array}$ & 21 & 568 & 20.686509 \\
\hline Aydinlatma & duvaraplik & $\begin{array}{l}\text { Avize } \\
\text { Marketim }\end{array}$ & $\begin{array}{l}\text { 2018-05- } \\
\text { 01T00:00:00 }\end{array}$ & 8 & 661 & 7.711717 \\
\hline
\end{tabular}

Şekil 22. Lineer (Doğrusal) Regresyon Modeli Tahmini Sonuçları

Şekil 20,21 ve 22 de farklı modellerin tahmini sonuçları yer almaktadır. Adet sütununda yer alan değerler firmanın gerçekleşen değerleridir. Scored Labels sütunu ise uygulama için seçtiğimiz modellerin tahmin ettiği sonuçlardır. Her üç modelinde gerçeğe yakın bir değeri tahmin ettiği gözükmektedir. Makine öğrenme modellerinde; veri setinin eğitim ve test için ayrılması, tahmin seçeneklerindeki yüzde başarısının artmasına sebep olduğu gözükmektedir. 
Model sonuçlarını grafiksel olarak değerlendirmek istediğimizde Azure ML'in kendi grafiksel desteğinin yanı sıra R Script araç kutusu ile istediğimiz grafikleri çizdirebiliriz.

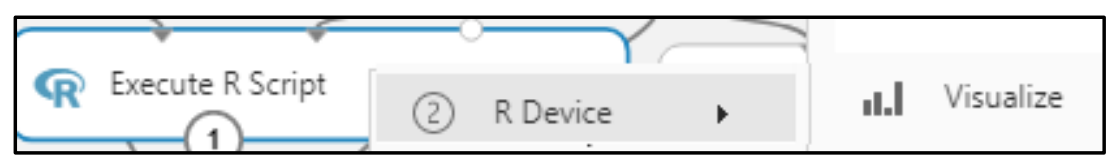

Şekil 23. R -Script Kod Yazma Araç Kutusu (Konteyner)

$\mathrm{R}$ dilinde yazılmış olan aşağıdaki kodlar, modellerin çıktılarını görsel olarak grafiklendirerek farklı yönden analiz desteği sağlamaktadır.

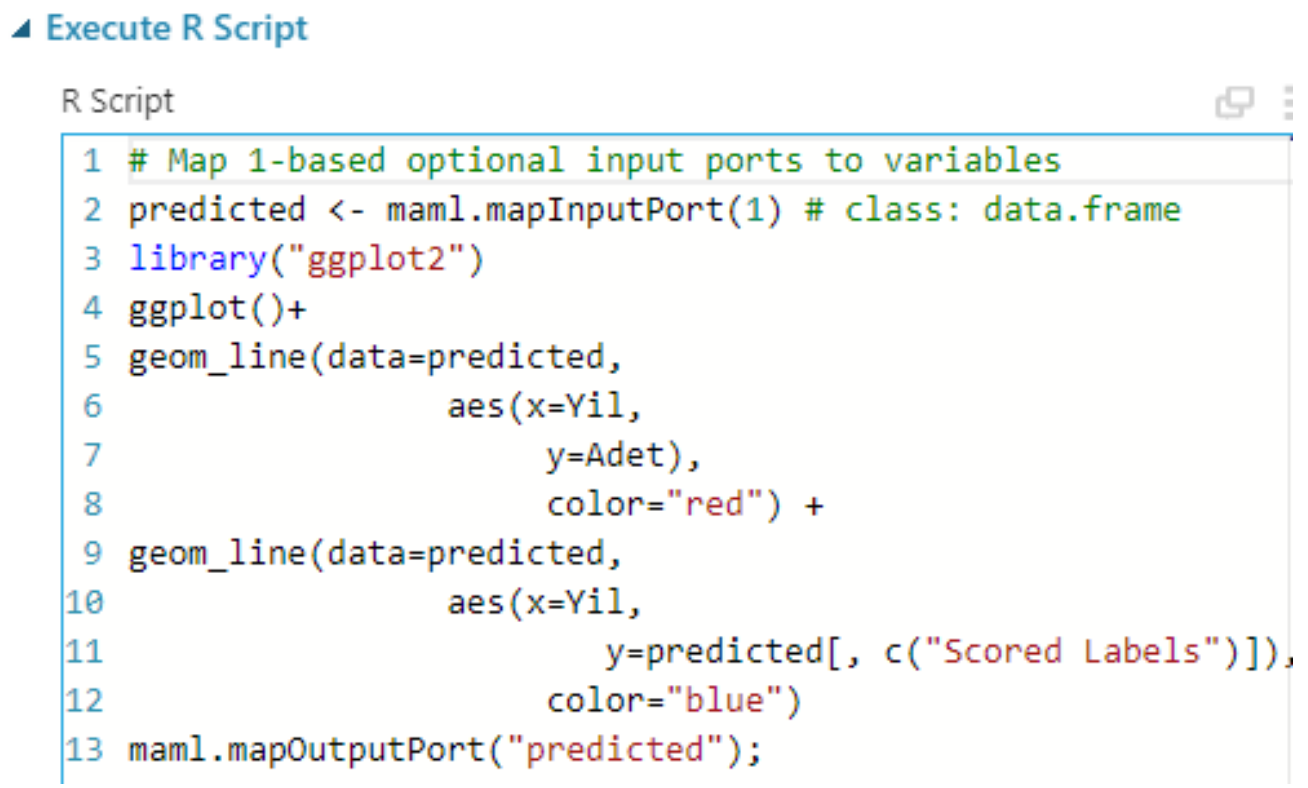

Şekil 24. Modülleri Grafiklerle Karşılaştıran R Kodları

Şekil 24 deki R kodları Azure ML tarafından desteklenen açık kaynak kodlu etkin istatistiki veri uygulamalar ve grafiksel çalışmalar için kullanılan bir programlama dilidir. Kodları çalıştırdığımızda; firmanın gerçekleşen değerleriyle, Doğrusal Regresyon modeli ile YSA modelinin tahmini değerlerinin karşılaştırmalı grafik görüntüsünü elde etmiş oluruz. 


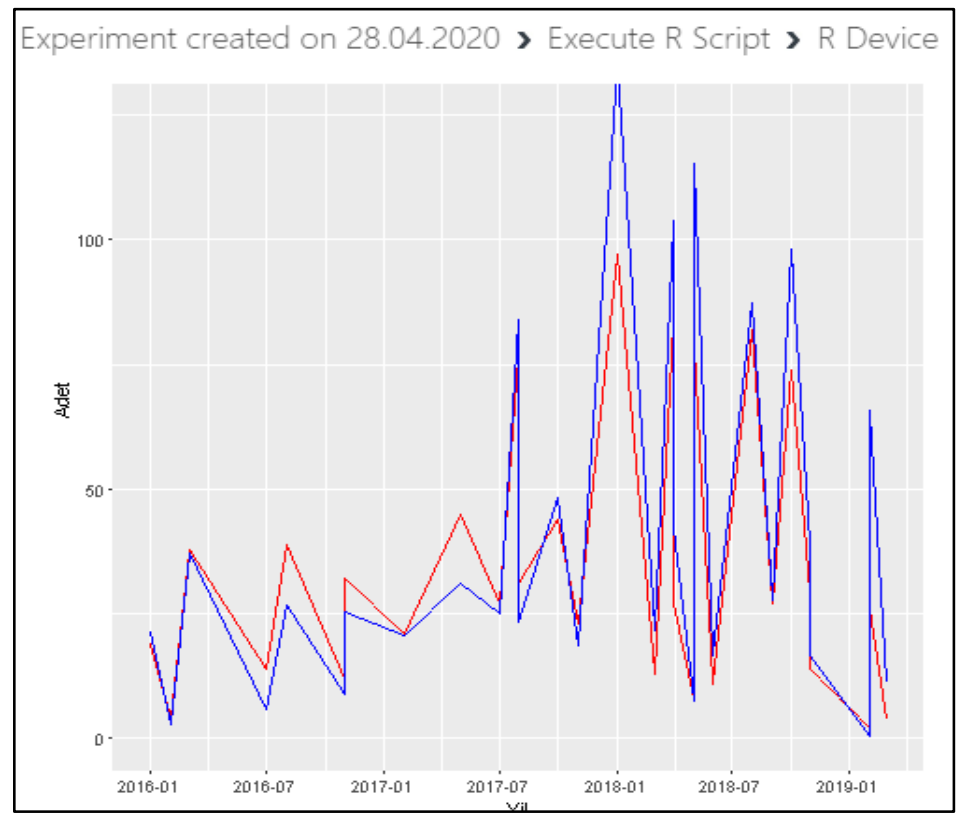

Şekil 25. Lineer - YSA Modeli Karşılaştırılması

Karşılaştırmalı modellerde; kırmızı olanlar gerçek değerler; mavi ve turuncu olanlar ise modelleri temsil eden tahmin edilen score label değerleridir. Grafik çizgilerindeki amaç, talepteki dalgalanmaları, aylık ölçümleri ve periyodik hareketleri izleyerek doğru tahminlerde bulunmaktır. Grafiklere baktığımızda, oluşturulan modellerin isabetli tahminler yaptığını görebiliyoruz

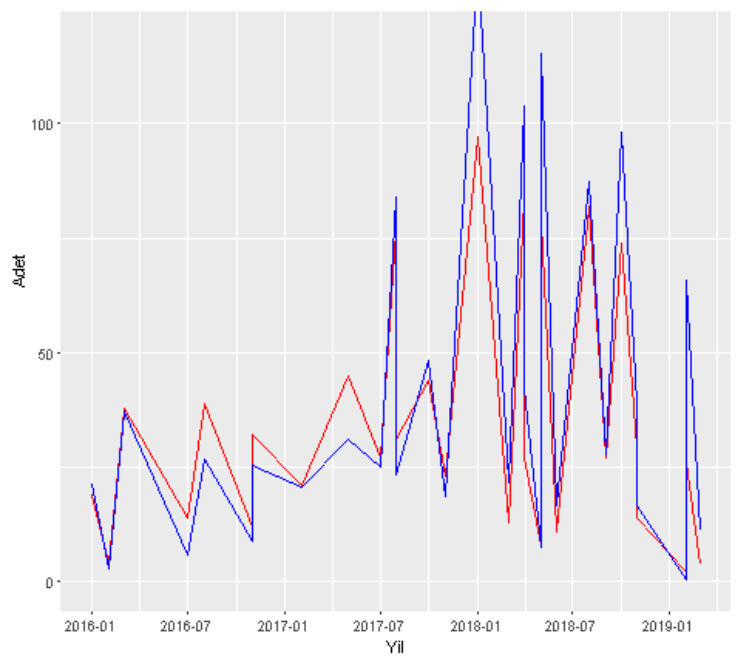

Şekil 26. Lineer ve BTR Modeli

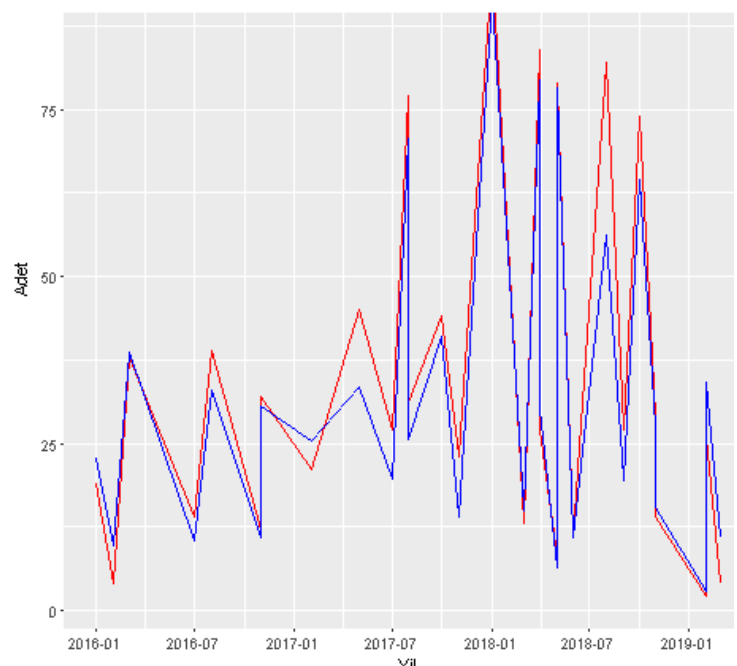

Şekil 27 YSA ve BTR Modeli

Veri analizinin geneline baktığınızda, gerçeğe yakın değerlerin çoğunlukta olduğu söylenebilir. Fakat binlerce ürün için tüm satırlara teker teker bakmak hem mümkün hemde rasyonel olmadığı için tahmin değerlerine yönelik performans için, tahmin değerlerinin (Score Label) gerçek değerden ne kadar saptığının hesaplanması model için daha gerçekçi olacaktır. Gerçek değerden sapmalarla ilgili kullanılan bazı kriterler olduğunu, 
Akar(2018:261),'Kriterlerin tamamının çıkış noktası, sapma ya da hata dediğimiz terimdir" sözleriyle aktarmıştır. Yazar;” verinin gerçek değeri ve öngörülen değeri arasındaki farka öngörü hatası ya da sapması ismi verildiğini” belirtmiştir. Bu söylenilenlere göre $X_{i}$ gerçek değer ve $F_{1}$ öngörü değeri olmak üzere

$$
\mathrm{E}_{1}=\mathrm{X}_{\mathrm{i}}-\mathrm{F}_{\mathrm{i}} \quad \text { şeklinde hesaplanır }
$$

\subsection{Model Ölçümünü Doğrulama Kriterleri}

Bir tahmini değerin doğrulama ölçümleri genelde aşağıdaki formüllerle hesaplanmaktadır. Model uygulamalarının tahmini hesaplama çıktılarını değerlendirmede, bu tür çalışmalarda sık olarak kullanılan ölçüm kriteri olarak MAPE değeri için en küçük olan, MSE ve RMSE değerlerinde ise sıfıra yakın olan sonuçlar dikkate alınmıştır.

Ortalama Mutlak Hata (MAE)

$M A E=\frac{1}{n} \sum_{i=0}^{n}\left|\mathrm{X}_{\mathrm{i}}-F_{i}\right|$

Ortalama Mutlak Hata Yüzdesi (MAPE)

$M A P E=\frac{1}{n} \sum_{i=0}^{n} \frac{\left|\mathrm{X}_{\mathrm{i}}-F_{i}\right|}{\left|\mathrm{X}_{\mathrm{i}}\right|}$

Ortalama Hata Kareleri (MSE)

$M S E=\frac{1}{n} \sum_{i=0}^{n}\left|\mathrm{X}_{\mathrm{i}}-F_{i}\right|^{2}$

Ortalama Hata Kareleri Kökü (RMSE)

$R M S E=\sqrt{\frac{1}{n} \sum_{i=0}^{n}\left|\mathrm{X}_{\mathrm{i}}-F_{i}\right|^{2}}$

Modelleri çalıştırdığımızda, gerçekleşen tahmin sapma hesaplamalarının sonuçlarını aşağıdaki Evaluate (Değerlendir) araç kutusu ile karşılaştırabiliriz.

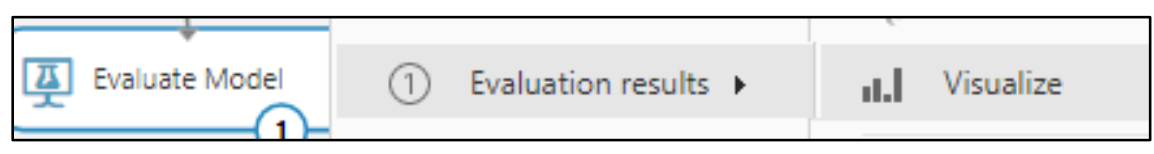

Şekil 28. Model Değerlendirme Aracı

Şekil 28' de Evaluation (Değerlendir) model konteyner üzerinde mouse'un sağ tuşuna tıklayıp, Results (sonuç) menü seçeneğinden Visualize(Görselleştir) seçildiğinde, öngörü ya da tahmin hata-sapma metrics (ölçüm) değerlerini hesaplatmış oluruz. Metrics değerleri; model tarafından üretilen tahmin değerlerinin, firmanın gerçekleşen adet değerlerinden, ne kadar uzakta veya yakında olduğunun değerlendirilmesine bir fikir sunar. 
Lineer - YSA

$\triangle$ Metrics

Mean Absolute Error

Root Mean Squared Error

Relative Absolute Error

Relative Squared Error

Coefficient of

Determination

9.691334
14.716867
0.450993
0.298703
0.701297

0.701297 $\triangle$ Metrics

$\begin{array}{ll}\text { Mean Absolute Error } & 5.008139 \\ \text { Root Mean Squared Error } & 7.000619 \\ \text { Relative Absolute Error } & 0.233057 \\ \text { Relative Squared Error } & 0.06759 \\ \text { Coefficient of } & 0.93241 \\ \text { Determination } & \end{array}$

Lineer - Boosted (BTR)

$\triangle$ Metrics

\begin{tabular}{ll}
\hline Mean Absolute Error & 9.691334 \\
Root Mean Squared Error & 14.716867 \\
Relative Absolute Error & 0.450993 \\
$\begin{array}{l}\text { Relative Squared Error } \\
\text { Coefficient of }\end{array}$ & 0.298703 \\
Determination & 0.701297 \\
\hline - Boosted (BTR) & \\
\hline Metrics & \\
\hline Mean Absolute Error & \\
Root Mean Squared Error & 7.008139 \\
Relative Absolute Error & 0.233057 \\
Relative Squared Error & 0.06759 \\
Coefficient of & 0.93241 \\
Determination &
\end{tabular}

\section{Metrics}

$\begin{array}{ll}\text { Mean Absolute Error } & 9.366228 \\ \text { Root Mean Squared Error } & 12.808654 \\ \text { Relative Absolute Error } & 0.435864 \\ \text { Relative Squared Error } & 0.226264 \\ \begin{array}{l}\text { Coefficient of } \\ \text { Determination }\end{array} & 0.773736\end{array}$

$\Delta$ Metrics

$\begin{array}{ll}\text { Mean Absolute Error } & 9.366228 \\ \text { Root Mean Squared Error } & 12.808654 \\ \text { Relative Absolute Error } & 0.435864 \\ \text { Relative Squared Error } & 0.226264 \\ \text { Coefficient of } & 0.773736 \\ \text { Determination } & \end{array}$

Şekil 29. Model Performans Sonuçlarının Değerlendirilmesi

Tablo 2. Tahmin Hata Değerleri

\begin{tabular}{|l|c|c|c|c|c|c|c|c|c|c|c|c|}
\hline \multirow{2}{*}{$\begin{array}{l}\text { Alt } \\
\text { Kategori }\end{array}$} & \multicolumn{3}{|c|}{$\begin{array}{c}\text { Lineer (Doğrusal) } \\
\text { Regresyon Modeli }\end{array}$} & \multicolumn{3}{c|}{$\begin{array}{c}\text { Boosted Decision Tree } \\
\text { Arttırılmış Karar Ağac1 }\end{array}$} & \multicolumn{3}{c|}{ YSA(Neural Network) } \\
\cline { 2 - 13 } & MAE & RSE & RMSE & MAPE & MAE & RSE & RMSE & MAPE & MAE & RSE & RMSE & MAPE \\
\hline $\begin{array}{l}\text { Duvar } \\
\text { Apliği }\end{array}$ & 9,69 & 0,29 & 14,7 & 0,28 & 9,3 & 0,22 & 12,8 & 0,27 & 5,0 & 0,06 & 7.0 & 0,14 \\
\hline $\begin{array}{l}\text { Cam } \\
\text { Avize }\end{array}$ & 25,8 & 0,78 & 36,8 & 0,97 & 13,7 & 0,30 & 22,9 & 0,51 & 5,6 & 0,03 & 7,89 & 0,21 \\
\hline $\begin{array}{l}\text { Kumaş } \\
\text { Sarkıt }\end{array}$ & 32,6 & 0,08 & 37,2 & 0,15 & 3,0 & 0,01 & 4,9 & 0,45 & 98,6 & 1 & 124,7 & 0,01 \\
\hline $\begin{array}{l}\text { Metal } \\
\text { Sarkıt }\end{array}$ & 35,4 & 0,03 & 65,9 & 0,18 & 232,3 & 1 & 360,1 & 1,20 & 88,0 & 0,24 & 176,9 & 0,45 \\
\hline Taş & 27,6 & 0,11 & 39,3 & 0,24 & 39,9 & 0,34 & 68,6 & 0,35 & 12,7 & 0,02 & 20 & 0,11 \\
\hline
\end{tabular}




\begin{tabular}{|l|c|c|c|c|c|c|c|c|c|c|c|c|}
\hline Avize & & & & & & & & & & & & \\
\hline $\begin{array}{l}\text { Tavan } \\
\text { Apligi }\end{array}$ & 10,95 & 0,66 & 12,5 & 0,66 & 11,18 & 1 & 15,3 & 0,67 & 4,89 & 0,16 & 6,25 & 0,29 \\
\hline Kitaplık & 87 & 0,02 & 1961 & 0,105 & 1110 & 1 & 13409 & 1,34 & 820 & 1,3 & 15727 & 0,99 \\
\hline
\end{tabular}

\section{Sonuç ve Öneriler}

Makine öğrenmesi platformunda Feature Selection (özellik seçimi) araçlarını kullandığımız bölümlerinin yer aldığı Șekil 10,11 ve 12 de, adet miktarını etki eden değişken ve alanlar sorgulanmıştır. Böylece gereksiz değişken ve alanlar çıkartılmıştır. Bu işlem için Pearson, Kendall ve Sperman korelasyon çeşitleri kullanılmış ve değişkenler arasındaki uyum ve doğrusal ilişki bağlantıları ölçülmüştür Buna göre adet değişkenini etkileyen en önemli değişken olarak Kendall 0,71, Pearson 0,96, Sperman 0,85 doğruluk değerlerine göre Ciro değişkeni çıkmıştır. Diğer değişkenlerin adet değişkenine etkisi sıfıra yakın değerler çıkmıştır. Metot sonuçlarına göre Ciro değerleri +1'e yakın değerler aldığı için Adet değişkeni ile aralarında pozitif ve anlamlı bir ilişki olduğu söylenebilmektedir (Çolak:2020:2). Makalelerinde; Kaçmaz ve Çam (2018:68) korelasyon katsayısını temsil eden r değişken değerini r=0,77 olarak bularak aralarında güçlü bir ilişki olduğunu belirtmişlerdir.

Modellerin Şekil 29 daki performans değerlendirme sonuçları için benzer bir çalışmada Kıvrak (2016:73), ölçüm kriterleri olarak sıfıra en yakın olan MSE ve RMSE değerleri alınması gerektiğini belirtmiştir. Tek bir alt-kategori için çalıştırılan model uygulamalarını, veri setinde yer alan tüm alt kategoriler için uygulayıp değerlendirdiğimizde Tablo 2'deki sonuçlara ulaşmış oluruz. Regresyon modelleri sonuçlarına göre MAPE ve RMSE değeri, gerçek değerler ile tahmin edilen değerler arasında son derece küçük sapmaları gösteren değerlerdir. (Chenn ve Wang,2007:218). MAPE tahmini; çıktı değerlerinin doğruluğunun değerlendirilmesi ve ölçümlenmesi için tahmini hata değerlerinin ölçülmesinde yaygın olarak kullanılır. MAPE; hata değerlerini yüzde olarak gösterir.MAPE değerleri \% 10'un altında olan tahmin modelleri "yüksek doğruluk" derecesine, \% 10 ile \% 20 arasında olan modeller ise doğru tahminler olarak sınıflandırmaktadır (Witt ve Witt,,1992:195). Tahmin hatalarının ölçümlenmesinde, yazında tüm atıflar, aşağıdaki tabloya dayandırılarak değerlendirilmiştir (Lewis, 1982:40). 
Tablo 3. Tipik MAPE Ölçüm Kriterleri (Yorumları)

\begin{tabular}{|l|l|}
\hline MAPE & Değerlendirme \\
\hline$<10$ & Doğruluğu Yüksek Tahmin \\
\hline$>=10 \& \&<20$ & İyi Tahmin \\
\hline$>=20 \& \&<=50$ & Makul Tahmin \\
\hline$>50$ & Hatalı Tahmin \\
\hline
\end{tabular}

Ürünlerin gelecekte ne kadar talep göreceğine ilişkin hazırlanmış olan tahmin modelleri; Tablo 3'de yer alan kriterler ve yazar Witt'e göre değerlendirildiğinde; Lineer regresyon modeli; Taş Avize, Tavan Apliği, Kumaş ve Metal Sarkit ve Kitaplık ürünlerinde; Boosted Decision Tree algoritmasına göre daha iyi tahmin değerlerine ulaşmıştır. Duvar Apliği ve Cam Avize ürünlerinde ise Boosted Decision Tree algoritması daha iyi performans göstermiştir. YSA(Neural Network) modeli ise; tüm ürünlerde her iki modelden daha iyi performans göstererek, çok düşük hata sapma (MAPE- RMSE) değerleri ile tahmin değerlerinin gerçeğe yakın ve güvenilir olduğunu göstermektedir. Elde edilen sonuçlar; aynı türden çalışmalar ile karşılaştırıldığında; Karahan(2015:169), İlhan,(2015:85), Moreno vd.(2013:501) benzer sonuçlar ile desteklendiği görülmüştür.

Uygulama için tasarlanmış modellerin performansı değerlendirmeleri için elde edilmiş olan değerler Erol ve İyi (2008:50) tarafindan yapılan çalışmalarla benzerlik göstermektedir. En iyi regresyon modelini seçme uygun bir regresyon modeli seçerken ilk adım, bağımlı değişkenle mantıksal ilişkisi olan bağımsız değişkenleri seçmektir.

Filtrelenmiş veriler üzerinde yaptığımız uygulamada Azure ML Studio platformunun veri işleme hızı ve tepki süresi ortalamanın üstünde bir performans göstermiştir. Makine öğrenme modelleri ve Hot-jar (müşteri tutumlarını online takip etme) uygulamaları kullanılarak, Eticaret faaliyetlerinde oluşan milyonlarca verinin işlenerek anlamlı hale getirilmesi gerekir. Tüketicilerin istek ve taleplerini kar getirecek şekilde karşılama işlemleri ancak bilgi ile olmaktadır. Makine öğrenme platformunda müşteriler için ürün önerme, benzer ürünleri seçenek olarak sunma gibi işlevlere sahip Train Matchbox Recommender modülü kullanılarak satış hacimleri arttırılabilir (Ayan,2018:25). Veri madenciliği çalışmaları için kümeleme modülleri karmaşık verilerin sınıflandırmasında katkıda bulunacak modüllerdir. 


\section{KAYNAKÇA}

Akar, Cüneyt. (2018). İş Analitiği. Bandırma: Dora.

Akyurt, İbrahim Zeki (2015). Talep Tahmininin Yapay Sinir Ağlarıyla Modellenmesi: Yerli Otomobil Örneği. İstanbul Üniversitesi İktisat Fakültesi Ekonometri ve İstatistik Dergisi, 147-157.

Arslan, Deniz; Bayırtepe, Hikmet (2018). Bitümlü Sıcak Karışımlara Ait Akma Değerinin Regresyon Modelleri İle Tahmini. Gazi Ü.Fen Bilimleri Dergisi, 45-53.

Ayan,Ahmet (2018), E-Ticaret Sitelerinin Satışlarının Artırılması İçin Bulut Bilişim Tabanlı Yapay Öğrenme, Necmettin Erbakan Üniversitesi Fen Bilimleri Enstitüsü Yüksek Lisans Tezi, Konya

Berg, Van Den; Zijm, Henk (1999). Models For Warehouse Management: Classipcation And Examples. Int. J. Production Economics, 519-528.

Chenn, Kuan-Yu; Wang, Cheng-Hua (2007). Support Vector Regression With Genetic Algorithms In Forecasting Tourism Demand. Tourism Management, 215-226.

Cho, Jay J.Kun; Ozment,J.;Sink, H (2008). Logistics Capability, Logistics Outsourcing And Firm Performance İn An E-Commerce Market. International Journal Of Physical Distribution \& Logistics Management, 336-360.

Croxton, Keely; Rogers, Dale S.(2001). The Supply Chain Management Processes. The International Journal of Logistics Management, 13-36.

Coolliler, Michael; Shahan Robin (2016), Microsoft Azure Essentials, Microsoft Press

Çam, Engin (2014). Dünü, Bugünü ve Yarını İle E-Ticaret: Karşılaşılan Sorunlar Ve Çözüm Önerileri, İnönü Üniversitesi Sosyal Bilimler Enstitüsü, Yüksek Lisans Tezi, Malatya

Çanc1, Metin; Erdal, Murat (2013). Lojistik Yönetimi. İstanbul: UTİKAD.

Elith, J.; Leathwick, J. R.; Hastie, T. (2008). A working guide to boosted regression trees. Journal of Animal Ecology, 802-813.

Eryürük Selin Hanife (2010). Tekstil ve Konfeksiyon Sektörleri Arasında Etkin Lojistik Faaliyetlerinin Gerçekleştirilmesi Amacıyla Bir Lojistik Merkez Yer Seçimi ve Tasarımı. İstanbul Teknik Üniversitesi Fen Bilimleri Enstitüsü Doktora Tezi.İstanbul

Chan Felix T.S.; Chan H.K. (2011). Improving The Productivity Of Order Picking Of A Manual-Pick And Multi-Level Rack Distribution Warehouse Through The İmplementation Of Class-Based Storage. Expert Systems With Applications, 2688-2700.

Goia, Aldo; May, Caterina; Fusai, Gianluca. (2010). Functional Clustering And Linear Regression For Peak Load Forecasting. International Journal Of Forecasting, 702-711.

Görçün, Ömer Faruk (2017). Depo ve Envanter Yönetimi. İstanbul: Beta.

Graham, Catherine H.; Elith, Jane (2006). Novel Methods İmprove Prediction Of Species' Distributions From Occurrence Data. Ecography, 129-151.

Gürdal, Sahavet (2006). Türkiye Lojistik Sektörü Altyapı Analizi. İstanbul: İTO.

Harper, Ralph L. (2010). Warehouse Technology in the Supply Chain Management Systems. Institute of Electrical and Electronics Engineers, 6-10.

Hauke, Jan; Kossowski, Tomasz (2011). Comparıson Of Values Of Pearson's And Spearman's Correlatıon Coefficients On The Same Sets Of Data., Quaestiones Geographicae, 87-93.

İlhan, İzzet (2015). Tedarik Zinciri Yönetiminde Kantitatif Talep Tahmin Yöntemi Seçimi İle Stok Optimizasyonuna Dair Bir Uygulama.. T.C.Maltepe Üniv. Fen Bilimleri Enstitüsü Yüksek Lisans Tezi. İstanbul

İyi, Pelin; Erol Hamza (2008), Çoklu Lineer Regresyonda En İyi Model Seçimi, Ç.Ü Fen Bilimleri EnstitüsüCilt:17-5

Karahan, Mehmet (2015). Yapay Sinir Ağları Metodu İle İhracat Miktarlarının Tahmini: Arıma ve YSA Metodunun Karşılaştırmalı Analizi. Ege Akademik Bakış, 165-172.

Kıvrak, Oğuzhan (2016), Müşteri Yaşam Boyu Değerinin Yapay Zeka Algoritmalarıyla Modellenmesi. Balıkesir Üniversitesi Sosyal Bilimler Enstitüsü Doktora Tezi, Balıkesir .

Koral, Yunus Emre (2009). Elektronik Ticaretin Lojistik Hizmet Kalitesine Etkisi. Marmara Üniversitesi Sosyal Bilimler Enstitüsü Yüksek Lisans Tezi .İstanbul

Koster, René B. M. De; Johnson, Andrew L.; Roya, Debjit (2017). Warehouse Design and Management. Informa UK Limited, Trading as Taylor \& Francis Group, 6327-6330.

Küçük, Orhan (2017). Stok Yönetimi. Ankara: Seçkin.

Lewis, C. (1982). Industrial And Business Forecasting Methods. London: Butterworths. Moreno Montaño, J. J., Palmer Pol, A., Sesé Abad, A., \& Cajal Blasco, B. (2013). Using The R-MAPE İndex As A Resistant Measure Of Forecast Accuracy. Psicothema, 500-506.

Özdemir, Sinan; Kakade, Sunil; Tibaldeschi, Marco (2018). Principles of Data Science. Birmingham: Packt Publishing. 
Perrealt, W.D.; McCarthy, E.J. (1996). Basic Marketing: A Global Managerial Approach. Chicago: Educarion Grp.

Qureshi, Shadid; Kretzer, Jan (2012). An Investigation of Antecedents and Outcomes of Marketing Capabilities in Entrepreneurial Firms: An Empirical Study of Small Technology-Based Firms in Germany. Journal of Small Business and Entrepreneurship, 24(1), 49-66.

Saatçioğlu, Ömür. (2019). Bilişim Sistemleri ve Lojistik. Eskişehir: Anadolu Kitap.

Saatçioğlu Derya(2016). Aralıklı Talep Yapısına Sahip Ürünlerin Talep Tahmininde Makine Öğrenme Yöntemlerinin Uygulanması. İstanbul.

Silveira, Giovani (2003). Towards A Frameworkfor Operations Management In E-Commerce. International Journal Of Operations \& Production Management, 23(2), 200-212.

Hompel,M; Schmid T.(2004).Warehouse Management, Springer.

Stevenson, William j.(2015). Operations Management. New York: McGraw Hill Internationa Edition.

Tanyaş, Mehmet(2005). Türkiye'de Lojistik Sektörü için Çözüm Önerileri,. İstanbul.

Tranmer, M., Murphy, J., Elliot, M., \& Pampaka, M. (2020). Multiple Linear Regression. Manchester: CC-BY licence.

Witt, Stephen F. Witt and Christine A. (1992). Modeling and forecasting demand in tourism. London: Academic Press.

\begin{tabular}{llcc} 
Çolak, & \multicolumn{1}{c}{ Ertuğrul } & Korelasyon & Analizi \\
& http://eczacilik.anadolu.edu.tr/bolumSayfalari/belgeler/ecz2014\%2012_20140527094539.pdf. & (Erişim \\
Tarihi : 29.04.2020) &
\end{tabular} 